\title{
PENGARUH PENAMBAHAN Crude Fish Oil (CFO) PADA PAKAN UDANG VANAME (Litopenaeus vannamei) TERHADAP KANDUNGAN KOLESTEROL DAN RETENSI LEMAK DAGING
}

\section{INFLUENCE OF ADDITION Crude Fish Oil (CFO) IN WHITE SHRIMP (Litopenaeus vannamei) FEED TO CHOLESTEROL CONTENT AND FAT RETENTION IN MEAT}

\author{
Agustono, Widya Paramitha Lokapirnasari dan Azharur Riyadh \\ Fakultas Perikanan dan Kelautan Universitas Airlangga \\ Kampus C Mulyorejo - Surabaya, 60115 Telp. 031-5911451
}

\begin{abstract}
White shrimp are aquatic organisms consumed by many people and a source of animal protein and fat needed by humans. Shrimp also require fat as a source of energy and metabolic processes to maximize growth. White shrimp meat contains high cholesterol so that it becomes an obstacle to consume white shrimp and high cholesterol in feed can affect the growth of shrimp. This problem can be solved by adding Crude Fish Oil (CFO) which contain high omega-3 fatty acids in white shrimp feed to decrease cholesterol content and source of dietary fat to increase fat retention in meat. The research problem is whether the addition of CFO in white shrimp feed effect on the decrease cholesterol content and increase of fat retention in meat. This research aims to determine the effect of CFO in white shrimp feed to decrease cholesterol and increase of fat retention in meat.

The method used is experimental method with Completely Randomized Design (CRD) as the experimental design. The treatment used is different persentage CFO addition to white shrimp feed, ie $\mathrm{P}_{0}$ $(0 \%), \mathrm{P}_{1}(2 \%), \mathrm{P}_{2}(4 \%), \mathrm{P}_{3}(6 \%)$ and $\mathrm{P}_{4}(8 \%)$ each treatment is repeated 4 times. Analysis of the data using Analysis of Varians (ANOVA) and to determine the best treatment performed Duncan's Multiple Range Test.

Results showed that the addition of CFO in feed give significant effect $(\mathrm{p}<0.05)$ to decrease the cholesterol content in meat. The best average decrease of cholesterol content obtained at $\mathrm{P}_{3}(135.22$ $\mathrm{mg} / 100 \mathrm{~g})$ and $\mathrm{P}_{4}(133.51 \mathrm{mg} / 100 \mathrm{~g})$. Addition of CFO in feed did not give significant effect $(\mathrm{p}>0.05)$ to increase fat retention in meat.
\end{abstract}

Keywords : crude fish oil, white shrimp, cholesterol, fat retention

\section{Pendahuluan}

Udang vaname memiliki manfaat sebagai sumber protein hewani, akan tetapi memiliki kelemahan yaitu memiliki kandungan kolesterol pada daging. Udang dianggap sebagai produk dengan kandungan kolesterol tinggi, karena mengandung lebih dari $150 \mathrm{mg}$ kolesterol/100 gram porsi yang dimakan (Ciaparra et al., 2005). Kandungan kolesterol yang berlebih pada pakan udang juga dapat mempengaruhi pertumbuhan udang. Pakan dengan kandungan 5\% kolesterol menekan pertumbuhan juvenil $P$. indicus (Changde and Raj, 1997).

Udang membutuhkan nutrisi pada pakan dalam bentuk lemak untuk memenuhi kebutuhan energi dan proses metabolisme. Lemak adalah sumber energi utama dan asam lemak esensial yang dibutuhkan untuk pertumbuhan dan perkembangan (NRC, 1993). Lemak yang telah diserap akan disimpan di dalam jaringan lemak yang disebut sebagai retensi lemak. Retensi lemak menggambarkan kemampuan ikan menyimpan dan memanfaatkan lemak pakan (Agustono dkk., 2011). Nilai retensi lemak pada daging dapat dijadikan sebagai indikator terpenuhinya kebutuhan lemak pada pakan yang telah diserap untuk memenuhi kebutuhan metabolisme pada udang vaname.

Hasil penelitian yang dilakukan oleh Lokapirnasari (2013) menunjukkan terjadinya penurunan kadar kolesterol pada serum broiler dari $162 \mathrm{mg} / \mathrm{dl}$ (kontrol atau 0\% minyak ikan) menjadi $134.00 \mathrm{mg} / \mathrm{dl}$ pada penambahan minyak ikan sebesar 2\%. Berdasarkan hal tersebut dapat diketahui bahwa asam lemak omega-3 berpengaruh terhadap kandungan kolesterol pada serum broiler melalui penambahan minyak ikan pada ransum pakan. Asam lemak tidak jenuh khususnya asam lemak omega-3 dapat menghambat sintesa Very Low Density Lipoprotein (VLDL) dan sebagai 
akibatnya produksi Low Density Lipoprotein (LDL) pun berkurang (Patawi, 1996).

Minyak ikan merupakan sumber lemak hewani dan mengandung asam lemak omega-3 dalam jumlah yang banyak. Kandungan lemak dan asam lemak omega-3 pada minyak ikan diharapkan dapat digunakan sebagai bahan untuk meningkatkan nilai retensi lemak dan menurunkan kandungan kolesterol pada daging melalui penambahan minyak ikan kasar atau Crude Fish Oil (CFO) pada ransum pakan udang. Hasil analisis yang telah dilakukan oleh Lokapirnasari (2013) Crude Fish Oil (CFO) memiliki kandungan lemak kasar sebesar $55,8791 \%$, asam lemak omega-3 yang tinggi yaitu Eicosapentaenoic Acid (EPA) sebesar 10,7173\% dan Docosahexaenoic Acid (DHA) sebesar 7,0108\%.

Rumusan Masalah

Apakah penambahan Crude Fish Oil (CFO) pada pakan berpengaruh terhadap penurunan kandungan kolesterol dan peningkatan retensi lemak daging udang vaname (Litopenaeus vannamei)?

Tujuan

Mengetahui pengaruh penambahan Crude Fish Oil (CFO) pada pakan terhadap penurunan kandungan kolesterol dan peningkatan retensi lemak daging udang vaname (Litopenaeus vannamei).

Manfaat

Manfaat dari penelitian ini yaitu dapat diketahui pengaruh penggunaan Crude Fish Oil (CFO) terhadap kandungan kolesterol dan nilai retensi lemak pada daging udang vaname dengan pemberian dosis yang berbeda. Menghasilkan udang vaname ukuran konsumsi dengan pertumbuhan yang baik dan memiliki kandungan kolesterol yang rendah untuk meningkatkan konsumsi udang masyarakat dan menjadi nilai tambah udang vaname Indonesia pada pasar ekspor udang. .

\section{Materi dan Metode}

Tempat dan waktu Penelitian

Penelitian ini dilaksanakan di Laboratorium Fakultas Perikanan dan Kelautan Universitas Airlangga pada bulan Maret sampai Mei 2014. Analisis kolesterol dan proksimat lemak dilakukan di Laboratorium Kimia Universitas Muhammadiyah Malang dan di Laboratorium Pakan Fakultas Kedokteran Hewan Universitas Airlangga.

\section{Materi Penelitian}

Peralatan penelitian yang digunakan pada penelitian ini yaitu: 20 buah akuarium, spektrofotometer, labu soxhlet, labu penyari, pendingin refflux, oven, exicator, timbangan analitik, cruss tang, kertas saring, aerator, 20 buah batu aerasi, selang aerasi, termometer, DO test kit, kertas lakmus, amonia test kit, refraktometer, beaker glass, sentrifuse.

Bahan yang digunakan pada penelitian ini yaitu: udang vaname (Litopenaeus vannamei) dengan berat rata-rata 5 gram/ekor sebanyak 200 ekor, minyak ikan kasar atau Crude Fish Oil (CFO), tepung ikan, dedak padi, bungkil kedelai, tapioka, tepung jagung, premix, air tawar, air laut, klorin, alkohol 96\%, petroleum benzene, alkohol, etanol, klorofom.

Metode Penelitian

Penelitian ini dilakukan dengan menggunakan metode percobaan dan rancangan percobaan yang digunakan pada penelitian ini yaitu Rancangan Acak Lengkap (RAL) sebab dalam penelitian ini hanya memiliki satu sumber keragaman yaitu Crude Fish Oil (CFO). Penelitian ini menggunakan 5 macam perlakuan dengan 4 ulangan pada setiap perlakuan. Analisis data yang digunakan yaitu Analysis of Varian (ANOVA) dan untuk mengetahui perbedaan antar perlakuan digunakan Uji Jarak Berganda Duncan.

\section{Hasil dan Pembahasan \\ Kolesterol}

Analisis dan penghitungan kandungan kolesterol pada daging udang vaname dari hasil perlakuan penambahan Crude Fish Oil (CFO) pada pakan dilakukan dengan alat spektrofotometer Hasil penghitungan Analysis of Varian (ANOVA) menunjukkan adanya pengaruh yang berbeda nyata $(\mathrm{p}<0,05)$ terhadap penurunan kandungan kolesterol daging udang vaname (Litopenaeus vannamei). Hasil Uji Jarak Berganda Duncan menunjukkan bahwa pada perlakuan $\mathrm{P}_{0}, \mathrm{P}_{1}, \mathrm{P}_{2}$ dan $\mathrm{P}_{3}$ memiliki perbedaan yang nyata antar perlakuan percobaan. Hasil penurunan kandungan kolesterol terendah didapat pada perlakuan $\mathrm{P}_{3}$ dan $\mathrm{P}_{4}$ akan tetapi tidak terdapat perbedaan yang nyata pada kedua perlakuan tersebut.

\begin{tabular}{cc}
\hline Perlakuan & $\begin{array}{c}\text { Kandungan Kolesterol } \\
\mathrm{mg} / 100 \mathrm{~g} \pm \mathrm{SD} .\end{array}$ \\
\hline P0 & $188,26^{\mathrm{a}} \pm 2,918$ \\
P1 & $171,65^{\mathrm{b}} \pm 7,201$ \\
P2 & $149,48^{\mathrm{c}} \pm 5.165$ \\
P3 & $135,22^{\mathrm{d}} \pm 3,175$ \\
P4 & $133,51^{\mathrm{d}} \pm 3,184$ \\
\hline
\end{tabular}

Tabel 1. Rata-rata Kandungan Kolesterol pada Daging Udang Vaname (Litopenaeus vannamei) 
Keterangan: Superscript yang berbeda pada kolom yang sama menunjukkan perbedaan yang nyata $(\mathrm{p}<0,05)$.

Pakan perlakuan yang tidak ditambahkan Crude Fish Oil (CFO 0\%) atau $\mathrm{P}_{0}$ memiliki kandungan kolesterol pada daging tertinggi yaitu sebesar $188,26 \mathrm{mg} / 100 \mathrm{~g}$. $\mathrm{P}_{1}$ (CFO 2\%) sebesar $171,65 \mathrm{mg} / 100 \mathrm{~g}$ dan $\mathrm{P}_{2}$ (CFO 4\%) sebesar 149,48 mg/100 g. Kandungan kolesterol terbaik didapat pada perlakuan $\mathrm{P}_{3}(\mathrm{CFO} 6 \%)$ dan $\mathrm{P}_{4}(\mathrm{CFO} 8 \%)$ secara berurutan memiliki kandungan kolesterol sebesar 135,22 mg/100 g dan sebesar 133,51 $\mathrm{mg} / 100 \mathrm{~g}$.

Kandungan kolesterol pada daging udang vaname (Litopenaeus vannamei) menunjukkan adanya perbedaan sesuai dengan peningkatan persentase penambahan Crude Fish Oil pada pakan. Komposisi daging udang sangat bervariasi tergantung pada jenis, tingkat umur, musim, habitat dan pakan udang tersebut (Zaitsev et al. 1969 dalam Pattawi 1996). Penyebab terjadinya perubahan kandungan kolesterol dapat terjadi akibat adanya proses penyerapan nutrisi pakan oleh udang. Sel mikrofili pada hepatopankreas menunjukkan fungsi sebagai tempat penyerapan makanan (Ceccaldi, 1989).

Penurunan kolesterol terendah pada daging udang vaname terdapat pada perlakuan $\mathrm{P}_{3}$ (CFO 6\%) dan $\mathrm{P}_{4}$ (CFO 8\%). Crude Fish Oil (CFO) adalah minyak ikan yang didapatkan dari hasil ekstraksi dan belum dilakukan proses pemurnian. Crude Fish Oil (CFO) memiliki kandungan lemak kasar sebesar 55,8791\%, asam lemak omega-3 yang tinggi yaitu Eicosapentaenoic Acid (EPA) sebesar 10,7173\% dan Docosahexaenoic Acid (DHA) sebesar 7,0108\% (Lokapirnasari, 2013). Kandungan asam lemak omega-3 (EPA dan DHA) yang tinggi pada CFO menyebabkan penurunan kolesterol daging udang vaname yang ditambahkan CFO pada pakan sebanyak 6\% dan 8\%. n-3 Polyunsaturated Fatty Acids (PUFAs) dari minyak ikan memiliki sifat yang sama dengan PUFAs nabati atau lebih bersifat hipolipidemik (Kinsella et al., 1990).

Hasil perlakuan penambahan crude fish oil pada pakan dapat menurunkan kandungan kolesterol hingga mencapai 133,51 mg/100 g pada perlakuan $\mathrm{P}_{4}(\mathrm{CFO} 8 \%)$. Penambahan $\mathrm{CFO}$ pada pakan udang vaname sebanyak $6 \%$ dan $8 \%$ dalam penelitian ini terbukti dapat menurunkan kandungan kolesterol pada daging udang vaname, nilai kolesterol udang vaname hasil perlakuan penambahan $\mathrm{CFO}$ lebih rendah jika dibandingkan dengan kandungan kolesterol pada daging udang atau pada kerang abalon dan cumi-cumi. Kandungan kolesterol pada daging udang dapat mencapai lebih dari $150 \mathrm{mg} / 100 \mathrm{~g}$ porsi yang dimakan (Ciaparra et al., 2005; Dayal, 2012). Kerang abalon (Haliotus cracherodi) sebesar $160 \mathrm{mg} / \%$ porsi yang dimakan dan cumi-cumi (Loligo opalescens) sebesar $339 \mathrm{mg} / \%$ porsi yang dimakan (Krzynowek and Murphy, 1987).

Proses penurunan kolesterol pada daging udang vaname oleh CFO dapat terjadi melalui proses penghambatan sintesis Very Low Density Lipoprotein (VLDL) dan Low Density Lipoprotein (LDL). Omega-3 dapat menurunkan kadar lipida (kolesterol) dalam serum darah, yaitu dengan jalan menghambat pembentukan protein dan trigliserida dalam VLDL atau LDL sehingga VLDL atau LDL dan kolesterol serum darah menjadi rendah (Manurung, 2009). Omega-3 dapat menghambat sintesa VLDL sebagai akibatnya produksi LDL juga berkurang (Pattawi, 1996).

Menurunnya kandungan kolesterol daging udang melalui penambahan CFO pada penelitian ini juga dapat terjadi melalui proses mekanisme peningkatan aktivitas metabolisme kolesterol dalam tubuh udang vaname. Mekanisme penurunan kolesterol total dan LDL terjadi melalui peningkatan pengambilan partikel LDL dari proses sirkulasi oleh liver (Rustan and Drevon, 2005). High Density Lipoprotein (HDL) membawa kolesterol yang sudah tidak digunakan oleh sel menuju liver untuk diperbaiki atau diekskresikan (Colpo, 2005).

Retensi Lemak

Analisis proksimat lemak pada daging udang vaname dari hasil perlakuan penambahan Crude Fish Oil (CFO) pada pakan dilakukan dengan metode soxhlet. Hasil penghitungan Analysis of Varian (ANOVA) menunjukkan tidak adanya pengaruh yang berbeda nyata $(\mathrm{p}>0,05)$ terhadap peningkatan retensi lemak daging udang vaname (Litopenaeus vannamei).

Tabel 2. Rata-rata Retensi Lemak pada Daging Udang Vaname (Litopenaeus vannamei)

\begin{tabular}{ccc}
\hline & \multicolumn{2}{c}{ Retensi Lemak } \\
\cline { 2 - 3 } Perlakuan & Data Asli & $\begin{array}{c}\text { Transformasi } \\
\sqrt{y}+0,5 \\
\% \pm \text { SD. }\end{array}$ \\
& $1,23 \pm 0,93$ & $1,32 \pm 0,35$ \\
P0 & $1,20 \pm 0,105$ & $1,30 \pm 0,041$ \\
P1 & $1,18 \pm 0,020$ & $1,30 \pm 0,007$ \\
P2 & $1,16 \pm 0,015$ & $1,29 \pm 0,006$ \\
P3 & $1,11 \pm 0,019$ & $1,27 \pm 0,008$ \\
P4 &
\end{tabular}


Persentase retensi lemak yang rendah didapatkan pada perlakuan $\mathrm{P}_{0}(\mathrm{CF} 00 \%)$ yaitu sebesar $1,23 \%$. $\mathrm{P}_{1}$ (CFO 2\%) sebesar $1,2 \%$ dan $\mathrm{P}_{2}$ (CFO 4\%) sebesar $1,18 \%$. Perlakuan $\mathrm{P}_{3}$ (CFO 6\%) sebesar 1,16 dan $\mathrm{P}_{4}$ (CFO 8\%) memiliki persentase sebesar $1,11 \%$.

Penghitungan nilai retensi lemak menunjukkan tidak adanya perbedaan yang signifikan dari hasil penambahan crude fish oil (CFO) pada pakan perlakuan percobaan. Perubahan nilai retensi lemak terjadi sesuai dengan peningkatan penambahan jumlah CFO yang ditambahkan pada pakan. Lipid yang terdapat pada pakan akan dicerna dan diserap pada organ pencernaan dan ditransport menuju sel untuk disimpan atau digunakan (Plascencia et al., 2000).

Analisis proksimat menunjukkan kadar lemak yang dapat disimpan pada daging udang vaname hasil perlakuan $\mathrm{P}_{0}(\mathrm{CFO} 0 \%)$ sampai $\mathrm{P}_{4}$ (CFO 8\%) secara berurutan yaitu sebesar 0,647$0,547 \%$. Hasil tersebut tidak jauh berbeda dengan hasil penelitian Pattawi (1996) yang menyatakan kadar lemak udang windu yang dipelihara secara intensif sebesar 0,43-0,50\%. Udang hanya memiliki kemampuan yang kecil untuk menyimpan lemak (Bureau et al, 2000).

Rendahnya kandungan lemak pada daging udang vaname percobaan $\left(\mathrm{P}_{4}\right.$ atau $\mathrm{CFO}$ $8 \%$ ) dapat dijadikan kesimpulan bahwa, lemak yang telah diserap dari proses pencernaan digunakan oleh udang percobaan sebagai sumber energi dan proses metabolisme lain. Lipid yang tersimpan ditransportasikan pada beberapa organ dan jaringan selama waktu tertentu seperti pada stadia premolt (Priya et al, 2013). Lemak dari pakan digunakan untuk energi dan memaksimalkan protein untuk proses pertumbuhan (Boonyaratpalin, 1996).

Hasil percobaan menunjukkan adanya penurunan persentase retensi lemak seiring dengan peningkatan kandungan lemak pakan yakni sebesar $1,23 \%$ pada perlakuan $\mathrm{P}_{0}(\mathrm{CFO}$ $0 \%$ ) dan $1,11 \%$ pada perlakuan $\mathrm{P}_{4}(\mathrm{CFO} 8 \%)$, hal ini menunjukkan bahwa lemak pada pakan dapat diserap dan digunakan sebagai sumber energi serta proses metabolisme tubuh udang vaname selama perlakuan percobaan. Du et al. (2005) menyatakan penurunan retensi lemak yang signifikan dengan peningkatan level lemak pakan, menunjukkan peningkatan proporsi lemak yang digunakan sebagai energi. Pakan yang mengandung lemak menjadi sumber asam lemak esensial, phospholipid, sterol dan karotenoid yang digunakan untuk pertumbuhan, survival dan metabolisme (Felix and Velasques, 2002).

\section{Kesimpulan}

Penambahan Crude Fish Oil (CFO) sebesar $6 \%$ dan $8 \%$ pada pakan dapat menurunkan kandungan kolesterol pada daging udang vaname (Litopenaeus vannamei) yaitu sebesar 135,22 mg/100 g dan 133,51 mg/100 g. Penambahan Crude Fish Oil (CFO) pada pakan tidak dapat meningkatkan nilai retensi lemak pada daging udang vaname (Litopenaeus vannamei) hasil perlakuan.

Perlu dilakukan penelitian lebih lanjut mengenai pengaruh tingkat penurunan kolesterol terhadap tingkat pertumbuhan atau Survival Rate (SR) ataupun penelitian sejenis yang bertujuan untuk meningkatkan produktifitas udang vaname (Litopenaeus vannamei) untuk meningkatkan konsumsi masyarakat terhadap udang.

\section{Daftar Pustaka}

Agustono., H. Setyono, T. Nurhajati, M. Lamid, M. A. Al-Arief, W. P. Lokapirnasari. 2011. Petunjuk Praktikum Nutrisi Ikan. Fakultas Perikanan dan Kelautan. Universitas Airlangga. Surabaya.

Boonyaratpalin, M. 1996. Nutritional Requirements of Commercially Important Shrimp in the Tropics. Proceedings of the National SeminarWorkshop on Fish Nutrition and Feeds. SEAFDEC Aquaculture Department, Iloilo, Philippines.

Bureau, D. P., P. A. Azevedo, M. T. Salazar, and G. Cuzon. 2000. Pattern and Cost of Growth and Nutrient Deposition in Fish and Shrimp: Potential Implications and Applications. Avances en Nutrición Acuícola V. Memorias del V Simposium Internacional de Nutrición Acuícola. 19-22 Noviembre. Mérida, Yucatán, Mexico.

Ceccaldi, H. J. 1989. Anatomy and Physiology of Digestive Tract of Crustaceans Decapods Reared in Aquaculture. Advances In Tropical Aquaculture Tahiti. February 20 - March 4, Aquacop.

Changde, M. S. and R. P. Raj. 1997. Cholesterol Requirement of Juvenile Indian White Prawn Penaeus indicus. J. Aqua. Trop., 12:227-237.

Cheng, Z. J. And B. W. Hardy. 2004. Protein And Lipid Sources Affect Cholesterol Concentrations Of Juvenile Pacific White Shrimp, Litopenaeus vannamei (Boone). J. Anim. Sci., 82:1136-1145. 
Ciapara, I. H., A.R. T. Guillen, L. N. Orozco, K.G. M. Robinson and M.C. E. Valle. 2005. Production Of a Low-Cholesterol Shrimp Using Supercritical Extraction. Journal of Food Process Engineering., 28:526-538

Colpo, A. 2005. LDL Cholesterol : "Bad" Cholesterol, or Bad Science?. Journal of American Physicians and Surgeons., 10(3):83-89.

Dayal, J. S., A. G. Poniah and K. Ambasankar. 2012. Shrimp as Health Food-Advisory Fact and Sheet. Central Institute Of Brackish Water Aquaculture (Indian Council of Agriculture Research). http://www.ciba.res.in. 10/09/2013.

Du, Z. Y., Y. J. Liu, L. X. Tian, J. T. Wang, Y. Wang, and G. Y. Liang. 2005. Effect of Dietary Lipid Level on Growth, Feed Utilization and Body Composition by Juvenile Grass Carp (Ctenopharyngodon idella). Aquaculture Nutrition 11; 139-146.

Felix, M. L. G. and M. P. Velazquez, 2002. Current Status of Lipid Nutrition of Pacific White Shrimp, Litopenaeus vannamei. Avances en Nutrición Acuícola VI.Memorias del VI Simposium Internacional de Nutrición Acuícola. 3 al 6 de Septiembre del 2002. Cancún, Quintana Roo, México.

Kinsella, J. E., B. Lokesh and R. A. Stone. 1990. Dietary n-3 Polyunsaturated Fatty Acids and Amelic Cardiovascular Disease: Possible Mechanism. Am. J. Clin. Nutr., 52:1-28.

Krzynowek, J. And J. Murphy. 1987. Proximate Composition, Energy, Fatty Acid, Sodium, and Cholesterol Content of Finfish, Shellfish and their Product. NOAA Technical Report NMFS 55.

Lokapirnasari, W. P. 2013. Potensi Inokulan Selulolitik Enterobacter cloacae dan Minyak Ikan untuk Meningkatkan Kualitas Pakan serta Implikasinya terhadap Penampilan Produksi dan Kualitas Daging Broiler. Disertasi. Program Studi Doktor Ilmu Kedokteran. Fakultas Kedokteran. Universitas Airlangga. Surabaya.
Lucas, J. S. and P. C. Southgate. 2003. Aquaculture Farming Aquatic Animal and Plants. Blackwell Publishing Company. Oxford. UK.

Manurung, D. M. 2009. Komposisi Kimia, Asam Lemak dan Kolesterol Udang Ronggeng (Harpiosquilla raphidea) Akibat Perebusan. Skripsi. Departemen Teknologi Hasil Perairan. Fakultas Perikanan Dan Ilmu Kelautan. Institut Pertanian Bogor.

National Research Council. 1993. Nutrient Requirement of Fish. National Academy Press. Wahington, D. C.

Patawi, A. 1996. Pengaruh Habitat Terhadap kandungan Asam Lemak Omega-3 dan Kolesterol pada Udang Windu (Penaeus monodon Fab). Skripsi. Program Studi Teknologi Hasil Perikanan. Fakultas Perikanan. Institut Pertanian Bogor.

Plascencia, G. Y., F. V. Albores, and I. H. Ciaparra. 2000. Penaeid Shrimp Hemolymph Lipoproteins. Aquaculture 191:177-189.

Poedjiadi, A. 1994. Dasar-Dasar Biokimia. UIPress. Salemba. Jakarta.

Priya, E. R., K. L. J. Kala, S. Ravichandran, and M. Chandran. 2013. Variation of Lipid Concentration in Some Edible Crabs. Journal of Fish and Marine Sciences 5 (1): 110-112.

Rustan, A. C. And C. A. Drevon. 2005. Fatty Acids: Structures and Properties. Encyclopedia of Life Sciences. John Willey and Sons, Ltd. 